\title{
An investigation into students' attitudes towards the value of poetry and their knowledge of poetry analysis
}

\author{
Ellen Turner (Lund University)
}

\begin{abstract}
Though poetry analysis is a central component of literary studies in higher education, research frequently reports that attitudes of both students and teachers to its incorporation in syllabi are mixed (Weaven \& Clark, 2014). Previous research suggests a complex relationship between attitudes to and knowledge of poetry with some studies indicating that negative attitudes might be the result of a lack of competency in analysing such texts (Benton, 1999; Fleming, 1992), and others suggesting the greater the knowledge, the less favourable the attitude (Liao \& Roy, 2017; Snapper, 2013). This small-scale quantitative study examines connections between knowledge and attitude in a sample of first-semester Swedish students of English, and investigates potential differences between pre-service teachers, and regular students.
\end{abstract}

\section{Introduction}

The benefits of studying poetry in higher education are widely recognised (Simecek \& Rumbold, 2016). Furthermore, poetry's image has had something of a makeover during the last decade, shaking off its pretentious exterior to gain more popular appeal (Dymoke, Lambirth \& Wilson, 2013). However, previous research exploring students' attitudes towards literature in general has exposed, in the words of Hirvela and Boyle, "an overwhelming preference for prose fiction, with an equally overwhelming distaste for poetry" (1988, p. 183). Though there is a dearth of research in relation to students' attitudes towards poetry, that which is available tends to reinforce these gloomy findings whilst concurrently recognising its inherent value (Fleming, 1992; Weaven \& Clark, 2014). From a methodological perspective, of the available research on attitudes to poetry, most have employed qualitative approaches (Certo, 2012; Vela et al., 2012; Weaven \& Clark, 2013; Xerri, 2014). Whether qualitative or quantitative, most existing research is on attitudes rather than knowledge, perhaps because such knowledge is particularly difficult to test; the practice of poetry analysis is inherently subjective (Bennett \& Royle, 2004, p. 12). As a corollary of the above factors, the link between attitudes towards poetry, and relevant knowledge, has yet to receive sustained attention.

Though studies that investigate the knowledge-attitude connection in relation to poetry are scarce, studies in other subject areas indicate some positive correlation between the two 
constructs (Alves-Martins, 2002; Neale, 1969; Reynolds \& Walberg, 1992). This present study examines whether these findings can be extended to the study of poetry in higher education by conducting a small-scale study into students' attitudes towards poetry in relation to their knowledge of terminology used in poetry analysis. The target population for this study are firstterm students of English in Sweden (both pre-service teachers and regular students).

This study explores whether negative perceptions of the study of poetry might be related to a perceived or actual deficit in the knowledge necessary for analysis of such texts. This project will look at differences in, and potential correlations between, knowledge and attitude towards poetry for pre-service teachers and regular students, as well as whether previous university level study and age has any bearing on these two constructs.

\subsection{Literature review}

As Dymoke et al. articulate, poetry in education has historically been subject to "woeful neglect" (p. 1). A reason for this is that poetry is perceived as "difficult" (Snapper, 2013). Research consistently reports anecdotal evidence that both teachers and students have a negative attitude towards the subject matter both in schools and in higher education (Benton, 1999; Fleming, 1992; Weaven \& Clark, 2014). It has been suggested that school students of English find their enjoyment of poetry decrease as academic demands increase, and that schoolleavers' knowledge of poetry is insufficient for university-level study (Snapper, 2013). One of the few studies into student attitudes to poetry in an English as a foreign language context indicate similar conclusions with the finding that the more poetry students read, "the lower confidence, desire, and interest they have toward writing poetry in English" (Liao \& Roy, 2017, p. 67). Furthermore, previous studies have explored teacher and pre-service-teacher attitudes to poetry (Wade \& Sidaway, 1990; Ray 1999). These stress that though teachers recognise the importance of poetry in the curriculum, they feel they lack sufficient knowledge for effective teaching. Exploring the gulf between provision for poetry in secondary education and higher education (HE), Weaven and Clark found that lack of poetry provision in schools is perpetuated by teachers who feel ill-prepared to teach poetry, despite being "unambiguous about the desirability of a restoration of poetry teaching in English" (2014, p. 148).

In a recent systematic literature review, Sigvardsson notes that "[i]n Sweden, poetry is an area of literature pedagogy that has for a long time been particularly understudied" (2017, p. 584). Sigvardsson points to a lack of resources for pre-service and in-service teachers in poetry teaching, an absence which is surprising given the Swedish curriculum's directive that 
poetry be an integral part of Swedish language education (Skolverket, 2011, as cited in Sigvardsson, 2017, p. 584). When it concerns teaching poetry in the English classroom in Sweden, lack of guidance is even more acute. Writing from within a Swedish context, Alfredsson states that though poetry is esteemed "within the school system," it is frequently "shunned" by educators" (2018, p. 238). Similarly, Nilsson has hinted that school students in Sweden may be opposed to engaging with "difficult" texts, such as poetry, because of "a lack of knowledge" (Nilsson, 2016, p. 2). In sum, previous research (including that with a specifically Swedish focus) tends towards a sense that there is a lack of provision for poetry thus fostering a negative attitude, but this is complicated by studies which equate higher demands on learning with lower levels of enjoyment.

There is little consensus about the nature of the correlation between attitude and attainment in education more broadly. General and non-subject-specific studies oftentimes conclude that there is a positive correlation (Alves-Martins, 2002; Kpolovie et al., 2014), but this is by no means categorical, with similar studies in subject-specific domains reporting inconsistent results. Though there is no existing study on the correlation in relation to the teaching of poetry in $\mathrm{HE}$, relevant studies have been conducted in relation to other subject areas, mostly targeting school-age learners. For instance, in relation to the study of mathematics in secondary school, Cheung found that if students recognised the benefit of mathematics in their everyday lives, their levels of attainment would be higher. Though a causal link between attitude and attainment could not be verified, Cheung's study suggested the reciprocal nature of the two constructs; whilst attitude affected attainment, attainment also impacted attitude (1988, p. 219). Studies in both mathematics education (Neale, 1969; Reynolds \& Walberg, 1992) and other subject areas such as physics (Pell, 1985), general science (Oliver \& Simpson, 1988), and chemistry (Nieswandt, 2007), support Cheung's findings. However, a meta-analysis of studies into attitude-achievement correlations suggests a complex interplay between variables, thus underscoring the importance of not oversimplifying any relationship (Ma \& Kishor, 1997).

Most existing research on attitude and attainment is in STEM (science, technology, engineering, and mathematics) education, but there is also a considerable body of research in the area of language learning. However, here correlations between attitude and attainment are less conclusive. Whilst Spolsky suggested that attitude does indeed play an important role in developing proficiency (1969), the existing literature is hesitant. For instance, Pierson et al. found that attitude was, contrary to expectations, not a significant predictor of attainment in relation to language proficiency for school learners of English as a foreign language (1980). In 
a similar study on Japanese students of English, only a weak correlation between attainment and achievement was found (Chihara \& Oiler, 1978).

Much like other aspects of the study of poetry, there is little by way of existing research investigating how age and educational background affect attitude and knowledge. One of the few existing studies in the area of literary studies more broadly suggests that negative attitudes are linked to backgrounds which limit students' exposure to relevant knowledge (Ghazali, 2008).

\subsection{Operationalisation of constructs}

Validity of instruments rests on successfully translating theoretical constructs into "empirically observable terms" so that theoretical concepts are closely related to measurable items (Jonker \& Pennink, 2010, p. 51). In this study, constructs were developed based on relevant theories of poetry analysis (Eagleton, 2007), in addition to a process of dialogue with subject experts (Isaacs, 1990). The operationalisation of the two constructs is outlined below.

The first construct, attitudes towards poetry, is defined as sentiments towards the study of poetry in an academic context, and sentiments about poetry more generally on a societal and personal level. A 20-item Likert scale was developed to measure the construct (see Appendix ). The second construct, knowledge of poetry, is slightly more complicated. As is demonstrated in the literature review, measuring knowledge of poetry is difficult. For the purposes of this study, knowledge of poetry is defined as an ability to identify key concepts and technical terminology relevant to the analysis of poetry. A 20 -item knowledge test was constructed in order to measure this construct (see Appendix 2).

\subsection{Hypotheses}

Below are listed the four hypotheses tested in this study, along with independent and dependent variables, and the relevant statistical test. Note that data meet the requirements for parametric testing. A brief explanation of how the hypotheses were informed by previous research follows this list.

H1 Students will have significantly different levels of knowledge of poetry analysis depending on whether they are studying English on the teacher education programme, or the regular English course. 
H01 There will be no statistically significant difference between levels of knowledge of poetry analysis depending on whether students are studying English on the teacher education programme, or the regular English course.

\begin{tabular}{ll}
\hline Independent variables & The type of course (regular or teacher education) \\
\hline Dependent variables & Knowledge of poetry analysis \\
\hline Statistical test & Independent samples t-test \\
\hline
\end{tabular}

H2 Students will have significantly different attitudes towards the value of the study of poetry depending on whether they are studying English on the teacher education programme, or the regular English course.

H02 There will be no statistically significant difference between attitudes towards the value of the study of poetry depending on whether they are studying English on the teacher education programme, or the regular English course.

\begin{tabular}{ll}
\hline Independent variables & The type of course (regular or teacher education) \\
\hline Dependent variables & Attitude towards the value of the study of poetry \\
\hline Statistical test & Independent samples t-test
\end{tabular}

H3 Students' attitudes towards the value of the study of poetry will correlate significantly with their knowledge of poetry analysis.

H03 There will be no statistically significant correlation between students' attitudes towards the value of the study of poetry and their knowledge of poetry analysis.

\begin{tabular}{ll}
\hline Independent variables & N/A \\
\hline Dependent variables & $\begin{array}{l}\text { Knowledge of poetry analysis and attitude towards the value of } \\
\text { the study of poetry }\end{array}$ \\
\hline Statistical test & Pearson product-moment correlation coefficient \\
\hline
\end{tabular}

H4 Students' attitudes towards the value of the study of poetry will be predictable based attitude will be predictable based on knowledge, type of English course, age and level of education. 
H04 Students' attitudes towards the value of the study of poetry will not be statistically predictable based on knowledge, type of English course, age and level of education.

\begin{tabular}{ll}
\hline Independent variables & Knowledge of poetry analysis \\
\hline Dependent variables & Attitudes towards the value of the study of poetry \\
\hline Statistical test & Multiple regression \\
\hline
\end{tabular}

Existing research suggests that teachers, though they feel ill-equipped to grapple with poetry, recognise its value (Ray, 1999; Snapper, 2013; Wade \& Sidaway, 1990). Consequently, one might expect to see a difference in both attitude and knowledge between students on the teacher education programme, and those who are studying English as a stand-alone subject thus justifying hypothesis 1 and 2. However, the lack of research into students who are not studying to become teachers, means the degree of confidence in relation to these hypotheses is low. As previously discussed, there are comparatively few attitude-attainment correlation studies within the humanities and, to the author's knowledge, none that deal specifically with poetry. Existing studies oscillate between suggesting a positive correlation (Alves-Martins, 2002; Kpolovie et al., 2014), and no significant correlation (Ma \& Kishor, 1997). There is low consensus on the correlation in language learning and humanities Chihara \& Oiler, 1978; Pierson et al., 1980). Though there is a lack of research in poetry in higher education, particularly in a Swedish context (Sigvardsson, 2017), the research suggests that there may be a link between knowledge and attitude to poetry (Nilsson, 2016). Thus, there is a relatively high degree of uncertainty in relation to hypotheses 3 and 4 which concern relationships between attitude and knowledge. Nevertheless, previous research supports a degree of positive correlation between the two constructs.

\section{Method}

This section details population and sampling, development of instruments, administration of instruments, and tests for reliability and validity. Specific procedures used to test hypotheses are presented in the results section.

\subsection{Population and sampling}

The target population for the study is entry-level students of English at a Swedish university. The accessible population is first level students of English at one Swedish higher 
education institution; one group is on an entry-level freestanding course on general English, and one group is studying English as part of a teacher-education programme.

Due to practical restrictions, convenience sampling was used. A convenience sample is, according to Henry, "a group of individuals who are readily available to participate in a study" (1990, p.18). There are inherent problems in terms of generalisability with such a nonprobability sample design (Oppenheim, 1992, p. 40). Of the two groups to which the instruments were administered, one had slightly more poetry instruction. The two groups did not attend the same lectures and had different instructors, which could have affected outcomes. A future study might choose to survey the students before they commence the introduction to literature module, thus minimising these differences between groups. Despite the wellrecognised problems with convenience sampling "often this is the only type of sampling possible." As is the case with this study, "the primary purpose of the research [is] not [...] to generalize but to better understand relationships that may exist" (McMillan, 1996, p. 91). Following recommendations to mitigate sampling problems, this study places emphasis on describing study conditions to avoid problematic interpretations (Farrokhi \& MahmoudiHamidabad, 2012, p. 792).

The sample consisted of 66 students, 37 of whom were studying English as part of a teacher-training programme. The remaining 29 were taking a similar module in English literature as part of a one-semester introduction to English course. All students were studying during the autumn of 2018. The mean age of students across the sample was 22.6 years, with a range of 25 from age 19 at the youngest, to age 44 at the oldest. Students had a mean of 39.7 university credits ( 30 credits equal one semester of full-time study). The number of credits held by students ranged from 0 to 196 (from first term to approximately three years of previous university-level education).

\subsection{Instruments}

The questionnaire consisted of three separate components: 1) background information; 2) attitude scale; and 3) knowledge test. In the below, the development of these instruments is described. Additionally, tests for reliability and validity are outlined.

The instrument developed for measuring attitude towards poetry was a 20 -item Likert scale (see Appendix ). Following recommended procedures, an item pool was compiled avoiding neutral/extreme statements (Oppenheim, 1992, p. 195). The scale was designed such that participants were asked to choose a place on a continuum from 5 (strongly agree) to 1 
(strongly disagree). A strong score represented a positive attitude, thus the scores for items that pertained to a negative attitude were subsequently reversed. This form of measurement was chosen since such scales aim at uni-dimesionality (Oppenheim, 1992, p. 195), and tend to be relatively reliable and simple to construct (Kumar, 2008, p. 108).

The attitude scale contains multiple items rather than a single item, with the purpose of eliminating bias or issues that may occur as a result of wording. In order to improve validity, the attitude scale was tested on several people known have a positive attitude (lecturers of English as well as more advanced students of English). As discussed below, efforts to minimise potential threats to validity through external factors were concerned in the administration.

Internal consistency testing using Cronbach's alpha was performed to confirm reliability, and the resultant Cronbach's Alpha was .842 . Since this score was greater than the .7 threshold, the items were deemed reliable (Pallant, 2005, p. 92). Deleting items 3 or 8 would have increased Cronbach's Alpha to .863 and .850 respectively. Since either of these modifications would have only resulted in minor increases, and following recommendations of Dörnyei \& Taguchithe (2010, p. 95), the decision was made to keep all 20 items.

The knowledge test consisted of 20 items (see Appendix 2). Each item asked the participant to choose the correct answer from a choice of 4 possible answers. The questions were developed to reflect a range of terminological knowledge with definitions drawn from several resources including The Poetry Foundations electronic "Glossary of Poetic Terms". General terminology was taken from the Merriam-Webster's online dictionary. Where questions involved authentic text samples, a variety of poems from various historical periods were used.

Measures were taken to ensure the validity of the knowledge test items. As an English Literature lecturer, I was able to use my experience of teaching literature to first-semester students to determine a suitable degree of difficulty for the items. One subject specialist (a professor of literature) was consulted and his insights led to altering one item in order to provide a less ambiguous example. A doctoral student of English education was also consulted and consequently the clarity of wording in relation to several items was improved. Both the aforementioned reviewers agreed that the instrument did measure the required construct and covered a range of relevant concepts. They also remarked that questions may prove relatively difficult for less experienced students, and this is an issue that would be revisited if this study were to run again. 
When the knowledge test items were analysed for reliability, the Cronbach's Alpha was .621. Guidelines vary as to reliable values with Pallant suggesting that values less than .7 indicate unreliability (2005, p. 92), whilst other sources claim a figure of .6 is the threshold (Bryman \& Cramer, 1997, p. 64). Since .621 is, at best, borderline, item reliability was further investigated (Pallant, 2005, p. 92). Item reliability was tested in SPSS for all the knowledge test items (Table 1).

\section{Table 1}

Item-total statistics for knowledge test questions

\begin{tabular}{|c|c|c|c|c|}
\hline & $\begin{array}{l}\text { Scale Mean if } \\
\text { Item Deleted }\end{array}$ & $\begin{array}{l}\text { Scale Variance if } \\
\text { Item Deleted }\end{array}$ & $\begin{array}{l}\text { Corrected Item- } \\
\text { Total Correlation }\end{array}$ & $\begin{array}{l}\text { Cronbach's Alpha } \\
\text { if Item Deleted }\end{array}$ \\
\hline Know1 & 8.4923 & 10.035 & .174 & .615 \\
\hline Know2 & 8.6923 & 9.779 & .292 & .599 \\
\hline Know3 & 8.8308 & 9.580 & .479 & .582 \\
\hline Know4 & 8.7077 & 10.179 & .156 & .617 \\
\hline Know5 & 8.3231 & 10.691 & -.022 & .639 \\
\hline Know6 & 8.4615 & 9.377 & .395 & .584 \\
\hline Know7 & 8.5692 & 9.999 & .189 & .613 \\
\hline Know8 & 8.2769 & 10.297 & .119 & .621 \\
\hline Know9 & 8.6923 & 10.623 & .002 & .636 \\
\hline Know10 & 8.4308 & 9.937 & .209 & .610 \\
\hline Know11 & 8.2923 & 9.648 & .346 & .592 \\
\hline Know12 & 8.5231 & 9.566 & .329 & .593 \\
\hline Know13 & 8.7231 & 10.235 & .141 & .618 \\
\hline Know14 & 8.6000 & 9.806 & .257 & .604 \\
\hline Know15 & 8.4769 & 9.816 & .246 & .605 \\
\hline Know16 & 8.7846 & 10.547 & .047 & .628 \\
\hline Know17 & 8.5077 & 9.473 & .360 & .589 \\
\hline Know18 & 8.2615 & 10.134 & .182 & .613 \\
\hline Know19 & 8.7077 & 10.116 & .177 & .614 \\
\hline Know20 & 8.6462 & 9.795 & .271 & .602 \\
\hline
\end{tabular}

Items $3,6,11,12$, and 17 in the knowledge test were shown to have a point-biserial correlation of above 0.3, which is considered good (Field, 2004, p. 713). However, there are competing ideas about the threshold for reliability. According to Varma (2016), in the context of tests in education, "a point-biserial value of at least .15 is recommended" though a value above 2.5 is desirable (p. 6). Of the items that fell below a value of .3, a decision was made to class any score that fell below .2 as unacceptable, and anything between .2 and .3 as workable. 
Items $2,10,14,15$, and 20 had a point-biserial correlation of $.2-.3$, and thus fell into the workable range. Items 5, 9 and 15 were shown to be poorly correlated with the overall scores. The other items' values were unacceptable at below 0.2. For items that fell in between 0.2 and 0.3 , item facility was investigated more closely. Item 2 and 20 had a facility percentage below $40 \%$ and thus were also deemed unacceptable for use in the data analysis. This left 8 items deemed usable. When all other items were deleted from the data, the Cronbach's Alpha decreased to 0.597. Since Cronbach's Alpha tends to increase with the number of items (Warner, 2008, p. 854), the decision was made to run the analysis with all the items.

The results concerning reliability of the knowledge test are disappointing and might weaken conclusions. If the study were run again, developing and testing the reliability of the test scores would be a priority.

The instruments were administered to both sets of students at the end of the final lecture of each respective course. Conditions for each group were kept as similar as possible, but some unavoidable external factors may have impacted on the validity of instruments. Prior to completing the questionnaire, I introduced the purpose of the study verbally, and emphasised the voluntary nature of participation (also detailed in writing on the coversheet for the questionnaire). Students were asked to place their completed surveys in a box as they left the lecture theatre. Several third-semester students piloted the combined set of instruments, and based on this, it was determined that 15 minutes be allowed for questionnaire completion. It is worth noting that for the regular student group, attendance was low for several possible reasons; the lecture was held early on a Monday morning and the group had an existing tendency towards low attendance, which was not the case with the pre-service-teacher group. This might suggest sampling bias since more motivated members of the group are likely to have been present.

\section{Results}

This section details the results of tests for normality, and the statistical tests used in relation to each of the four hypotheses.

\subsection{Testing for normal distribution of data}

Kolmogorov-Smirnov and Shapiro-Wilk tests were used to test for normality to determine whether parametric tests should be used. Table 2 shows the results for the entire 
sample. The normality tests were run on all continuous variables. Table 3 displays the separate results for the two subgroups (pre-service teacher and regular student).

Table 2

Test of normality for entire sample

\begin{tabular}{lllllll} 
& \multicolumn{5}{l}{ Kolmogorov-Smirnov } & \multicolumn{3}{c}{ Shapiro-Wilk } \\
\cline { 2 - 7 } & Statistic & df & Sig. & Statistic & Df & Sig. \\
\hline Total attitude score &, 061 & 65 &, $200^{*}$ &, 986 & 65 &, 689 \\
\hline Knowledge total &, 088 & 65 &, $200^{*}$ &, 966 & 65 &, 075 \\
\hline
\end{tabular}

Table 3

Test of normality for the two subgroups

Teacher or regular

student Kolmogorov-Smirnov ${ }^{\mathrm{a}}$

Shapiro-Wilk

\begin{tabular}{lllllllc}
\hline & & Statistic & Df & Sig. & Statistic df & Sig. \\
\hline \multirow{2}{*}{$\begin{array}{l}\text { Total attitude } \\
\text { score }\end{array}$} & Regular &, 060 & 29 &, $200^{*}$ &, 991 & 29 &, 996 \\
\cline { 2 - 7 } & Teacher &, 074 & 36 &, $200^{*}$ &, 985 & 36 &, 893 \\
\hline \multirow{2}{*}{$\begin{array}{l}\text { Knowledge } \\
\text { total }\end{array}$} & Regular &, 151 & 29 &, 090 &, 924 & 29 &, 037 \\
\cline { 2 - 7 } & Teacher &, 139 & 36 &, 078 &, 966 & 36 &, 335
\end{tabular}

In most cases the p-value of the Shapiro-Wilk test was above .05, indicating normal distribution (Pallant, 2005, p. 57). The result of the Shapiro-Wilk test was supported by the Kolmogorov-Smirnov test. The exception was the total knowledge score for the regular-student subgroup with a p-value of .037 on the Shapiro-Wilk test. However, the Kolmogorov-Smirnov test showed a value of .09 putting it in the normal range. In all but the knowledge variable for the regular students, differences between the mean and trimmed mean were small.

The skewness and kurtosis values for total attitude and total knowledge scores are displayed in

Table 4. The most significant deviation from the norm rests with the knowledge score for the regular students. Here the values reveal a positive skew of 1.011 and a leptokurtic distribution with a value of 1.266. George and Mallery (2016) state that though skewness and kurtosis values of between \pm 1 are "considered excellent," a value of between \pm 2 "is in many cases also acceptable" (p. 114). Thus, the values for the knowledge score for regular students fall within acceptable limits. The values in the other cases did not reveal major deviations and were all within the \pm 1 value suggested by George and Mallery as a good rule of thumb for excellent normal distribution (2016, p. 114). 
Table 4

Skewness and kurtosis values for total attitude and total knowledge scores

\begin{tabular}{lll} 
& Skewness & Kurtosis \\
\hline Regular students: attitude score &,- 102 &,- 137 \\
\hline Pre-service teacher students: attitude score &,- 091 &,- 186 \\
\hline Regular students: knowledge score & 1,011 & 1,266 \\
\hline Pre-service teacher students: knowledge score &, 112 &,- 625 \\
\hline
\end{tabular}

As shown in Figure 1, the histogram produced for the knowledge variable reflected the slight deviation from normal distribution and highlighted potential outliers, though the histogram for attitude variable more closely resembled the bell curve (Figure 2). When this was more closely investigated for the separate categories of regular and pre-service teachers, the histograms revealed that outliers lay with the regular-student group, as shown in Figure 3. This was consistent with the results for normality tests discussed above. Figure 4 identifies the two problematic cases (25 and 11). In accordance with Field's recommendations (2014, p. 177), the raw data were rechecked, and deemed accurate. According to Osbourne and Overbay outliers should be taken seriously in data analysis since there is "a strong beneficial effect of removal of extreme scores" (2004, p. 1). However, Osbourne and Overbay note that it is important to distinguish outliers from dubious values, the latter of which are more problematic. In this case, the score of 17 out of 20 for the knowledge test occurs twice, and given the small sample size, this is not particularly surprising. It is not legitimate to drop the outliers just because they are outliers. Since removing these scores could affect comparison with the preservice teacher group, a decision was made to analyse the data with the outliers. On balance, the upshot of the normality tests was that parametric tests should be used across the board. 
Figure 1

Histogram for knowledge

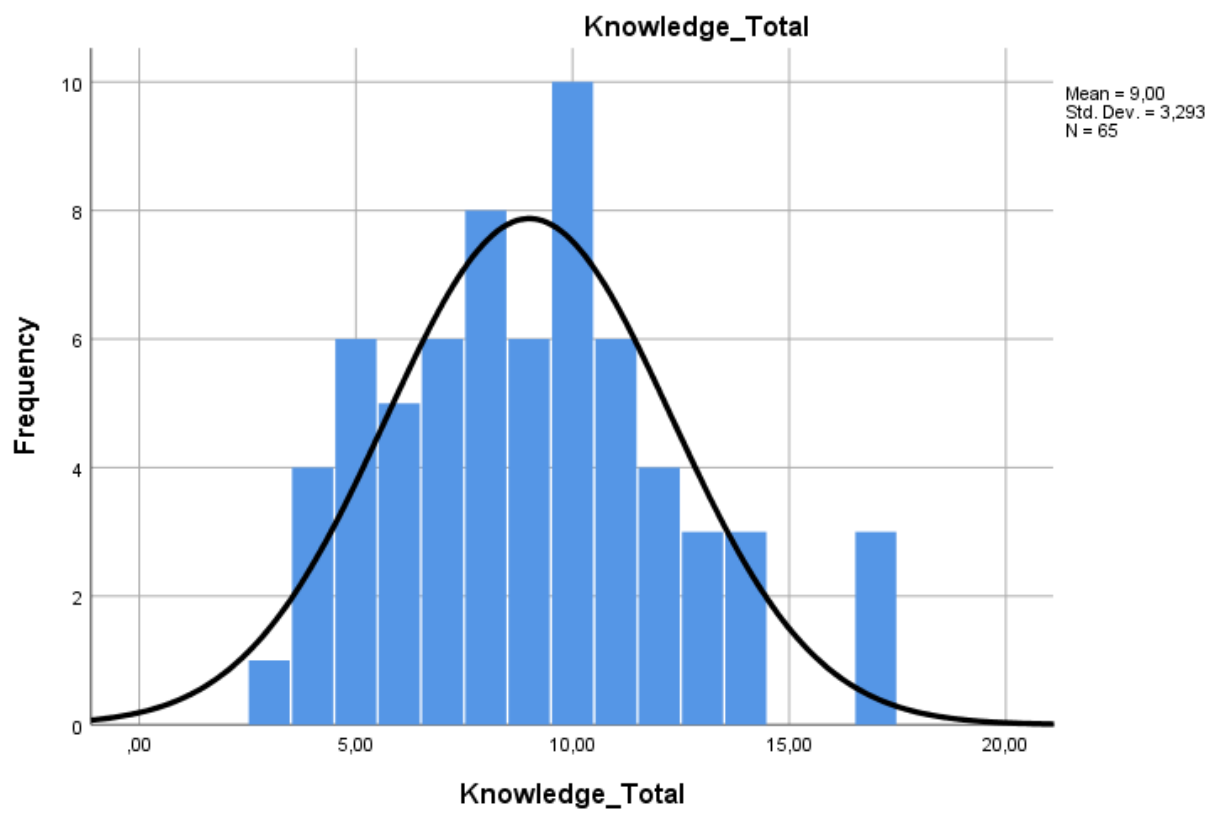

Figure 2

Histogram for attitude

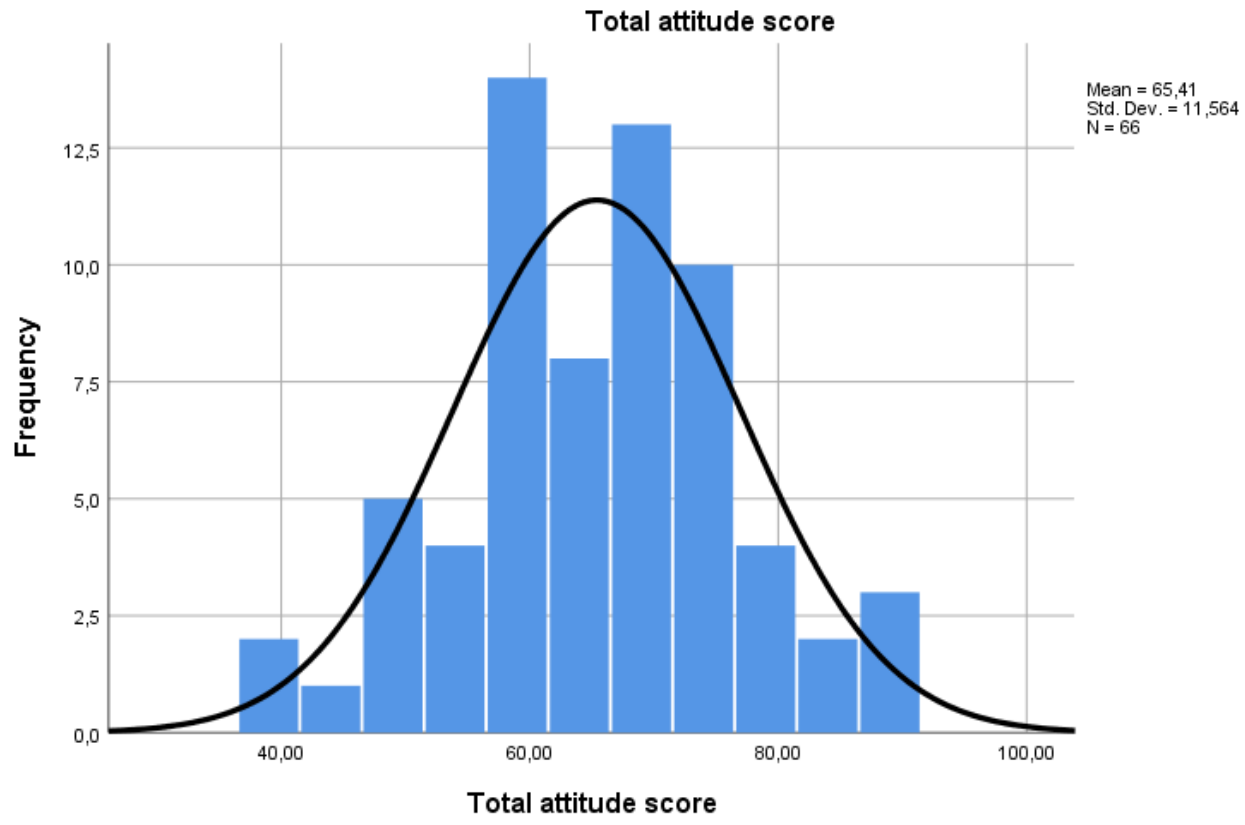


Figure 3

Histogram for knowledge (regular students)

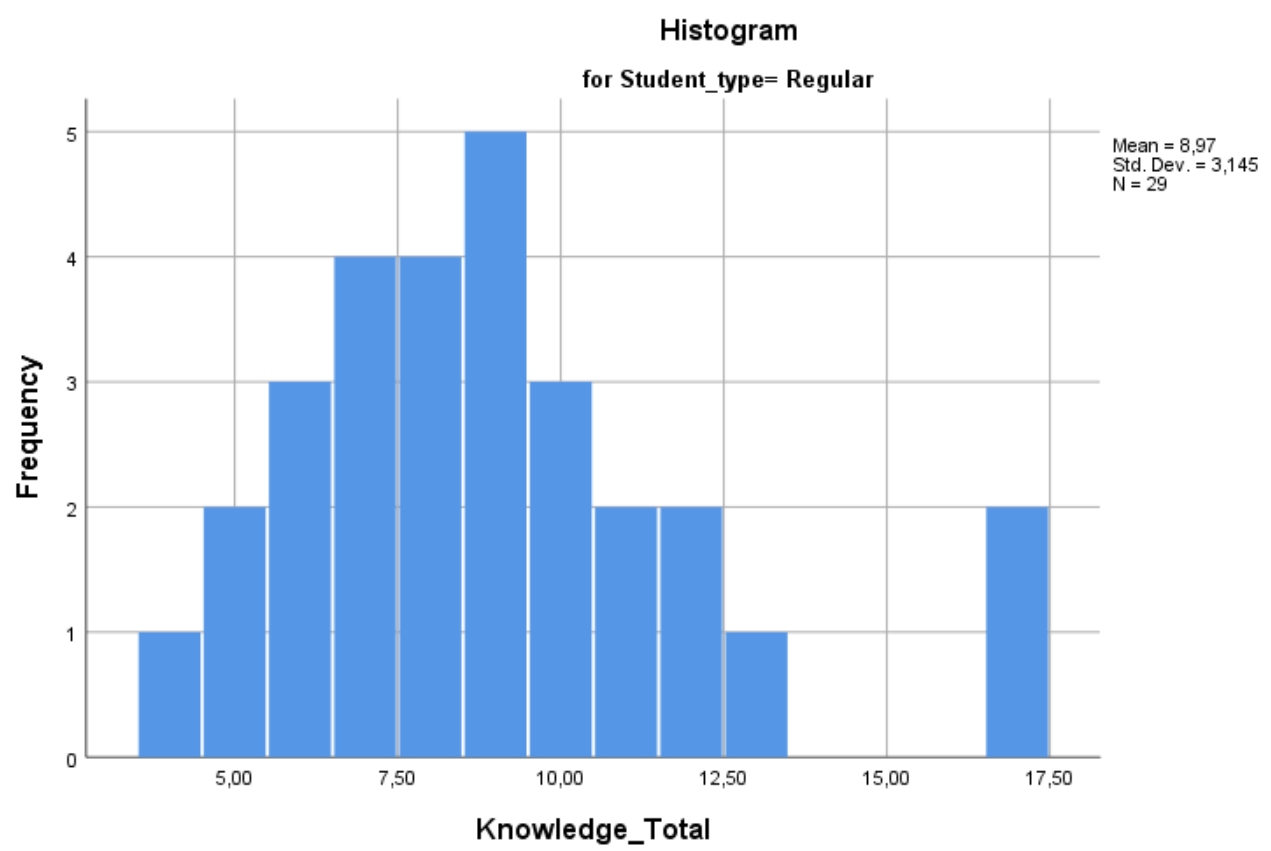

Figure 4

Outliers

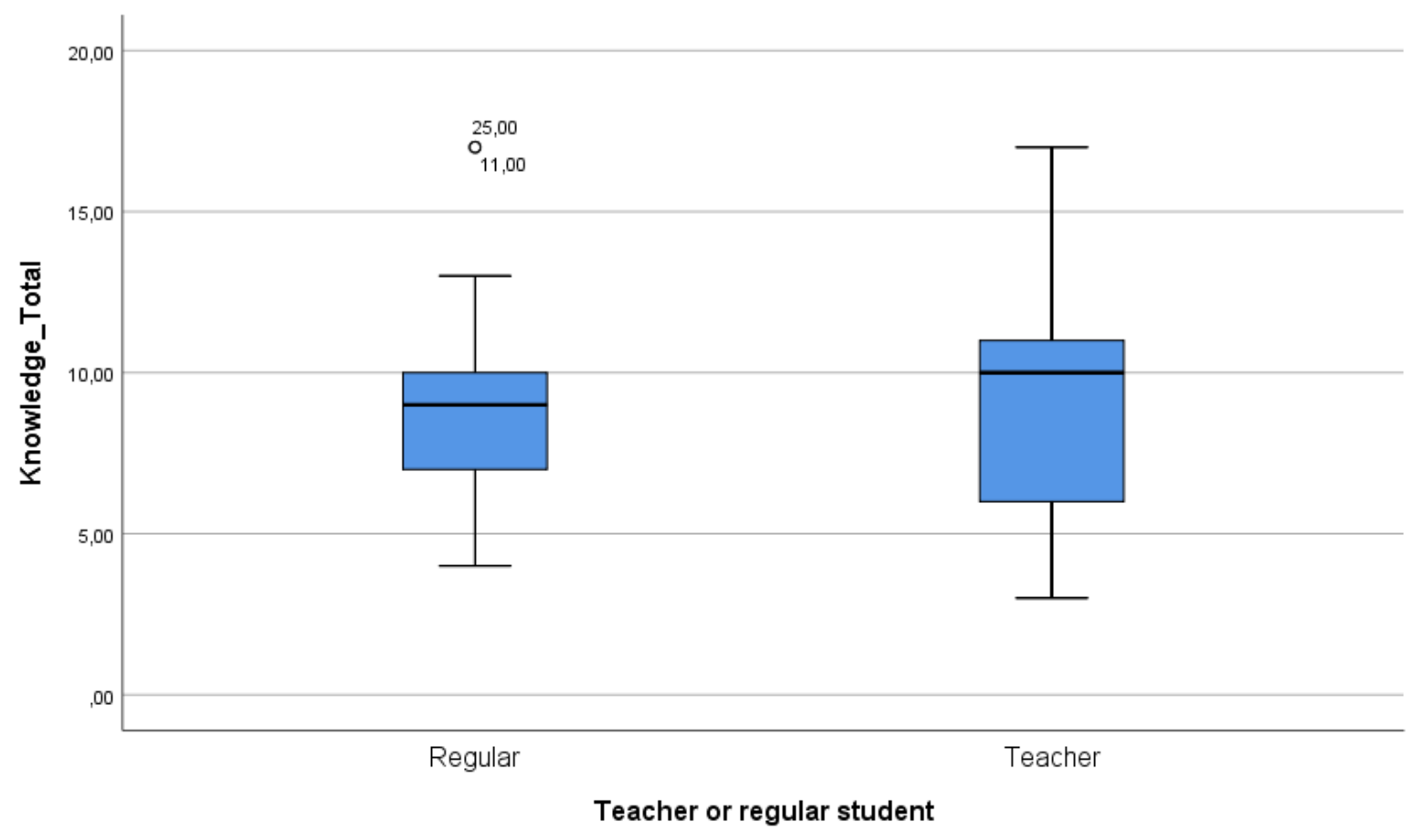




\subsection{Tests of hypotheses}

\subsubsection{Hypothesis 1}

To test whether levels of knowledge of poetry analysis differed significantly between students studying on the teacher-education programme and regular students, an independent samples T-test was performed. The group statistics output is presented in Table 5 and the result of the independent samples test in Table 6. There was no significant difference in the knowledge scores for regular students $(\mathrm{M}=8.9655, \mathrm{SD}=3.14510)$ and teacher education students $(\mathrm{M}=9.0278, \mathrm{SD}=3.45159) ; \mathrm{t}(63)=-.075, \mathrm{p}=0.940$. Even though the mean knowledge score for the teacher education students was marginally higher, the significance value of 0.940 is well above the threshold of 0.05 and thus is not statistically significant.

Table 5

Group statistics for knowledge and course type

\begin{tabular}{|c|c|c|c|c|c|}
\hline & Teacher or regular student & $\mathrm{N}$ & Mean & Std. Deviation & Std. Error Mean \\
\hline \multirow[t]{2}{*}{ Knowledge total } & Regular & 29 & 8.9655 & 3.14510 & .58403 \\
\hline & Teacher & 36 & 9.0278 & 3.45159 & .57527 \\
\hline
\end{tabular}

Table 6

Independent samples test for knowledge and course type

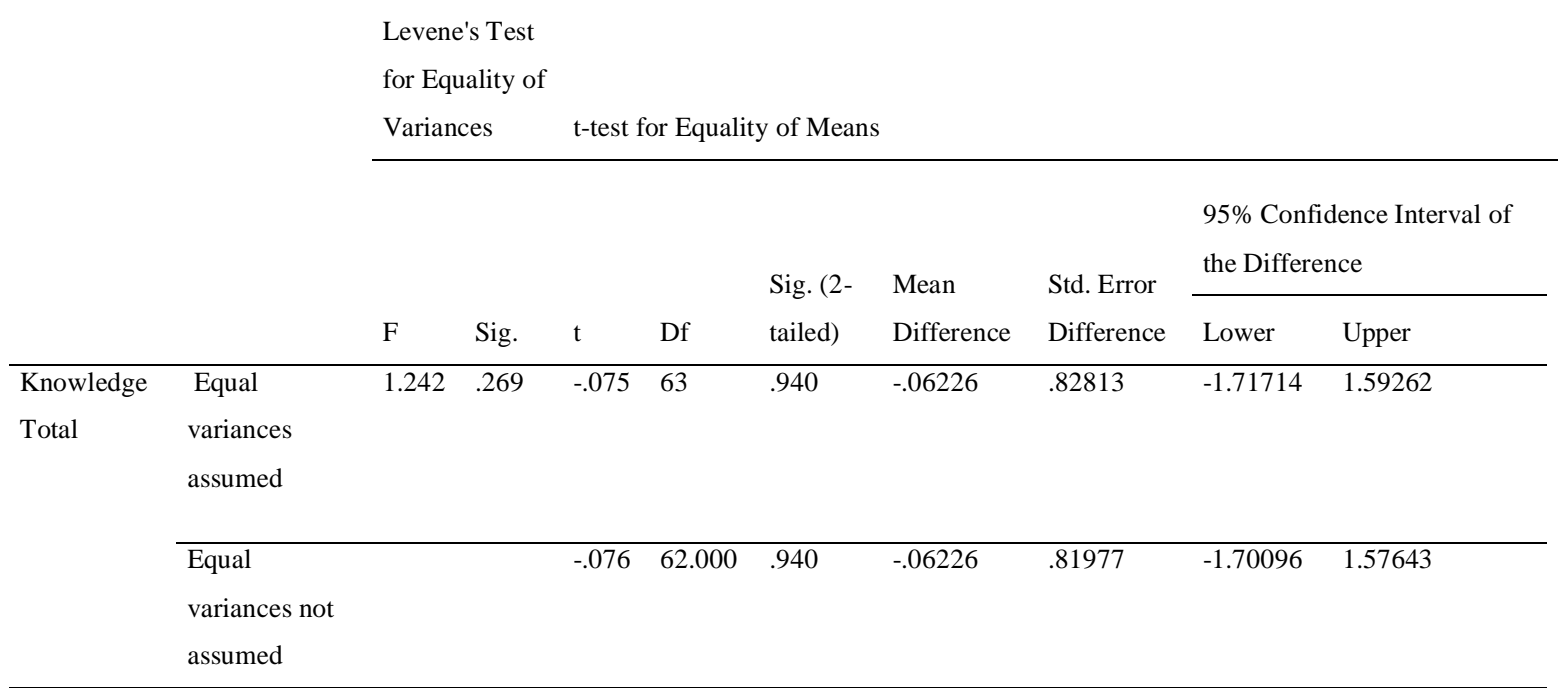

H1 Students will have significantly different levels of knowledge of poetry analysis depending on whether they are studying English on the teacher education programme, or the regular English course. Rejected. 
H01 There will be no statistically significant difference between levels of knowledge of poetry analysis depending on whether students are studying English on the teacher education programme, or the regular English course. Accepted.

\subsubsection{Hypothesis 2}

An independent samples T-test was performed in order to determine whether there was a statistically significant difference between the two sets of students. The group statistics are presented in Table 7 and the independent samples test results in Table 8. There was no significant difference in the attitude scores for regular students $(M=65.4828, S D=11.38175)$ and teacher education students $(\mathrm{M}=65.3514, \mathrm{SD}=11.86080) ; \mathrm{t}(64)=0.25, \mathrm{p}=0.964$. The significance value of 0.964 is greater than 0.05 and thus the difference between the two groups is not significant.

Table 7

Group statistics for attitude and course type

\begin{tabular}{llllll} 
& Teacher or regular student & $\mathrm{N}$ & Mean & Std. Deviation & Std. Error Mean \\
\hline Total attitude score & Regular & 29 & 65.4828 & 11.38175 & 2.11354 \\
& & & & & \\
\cline { 2 - 5 } & Teacher & 37 & 65.3514 & 11.86080 & 1.94990 \\
\hline
\end{tabular}

Table 8

Independent samples test for attitude and course type

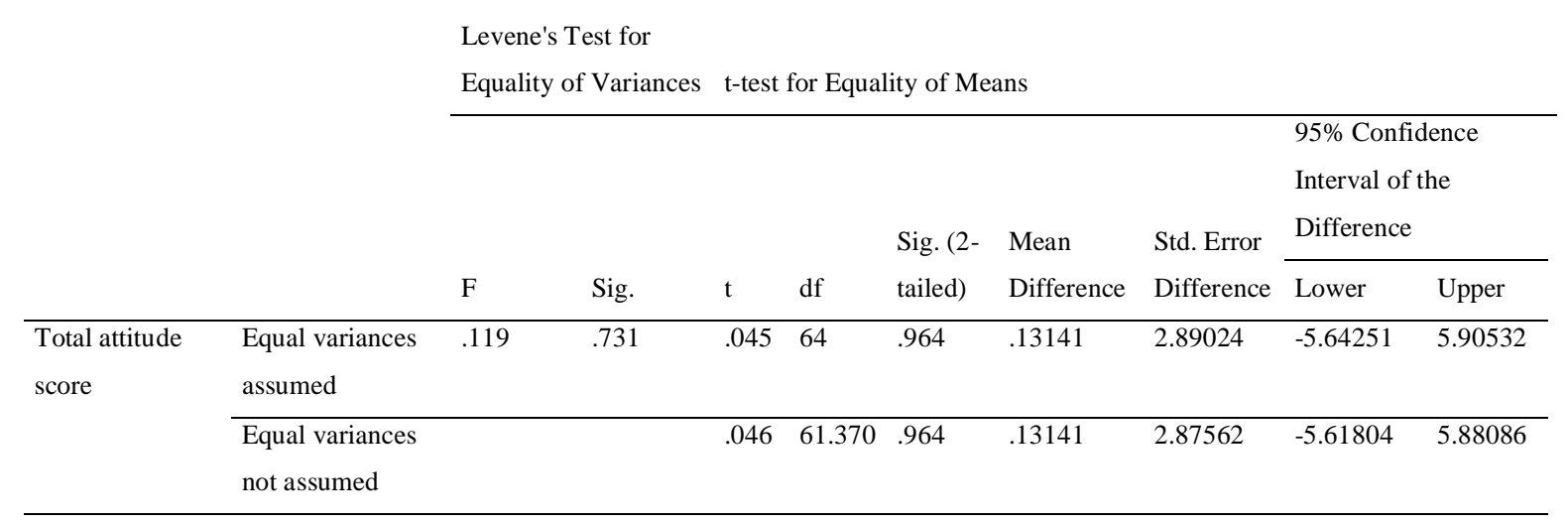

H2 Students will have significantly different attitudes towards the value of the study of poetry depending on whether they are studying English on the teacher education programme, or the regular English course. Rejected 
H02 There will be no statistically significant difference between attitudes towards the value of the study of poetry depending on whether they are studying English on the teacher education programme, or the regular English course. Accepted

\subsubsection{Hypothesis 3}

In order to test for a possible correlation between knowledge and attitude, a Pearson correlation coefficient test was used. The results of this are presented in Table 9. There was only a weak positive correlation between the two variables, $r=0.13, n=65, p=0.303$. Pallant notes that there are various approaches to interpreting values but suggests Cohen's guidelines (1988) which classify a Pearson correlation value of between 0.10 to 0.29 as a small positive correlation (2005, p. 126). This is supported by Field's suggestion that a value of 0.1 represents only a small correlation (2014, p. 82) and Cohen and Holliday's recommendation that any value below 0.19 is very low (1982). Since the value of 0.130 falls at the lower end of suggested scales, it was determined that only a weak correlation is present. The scatter graph in Figure 5 gives a visual representation of the weak correlation.

Figure 5

Simple scatter graph of attitude score by knowledge score

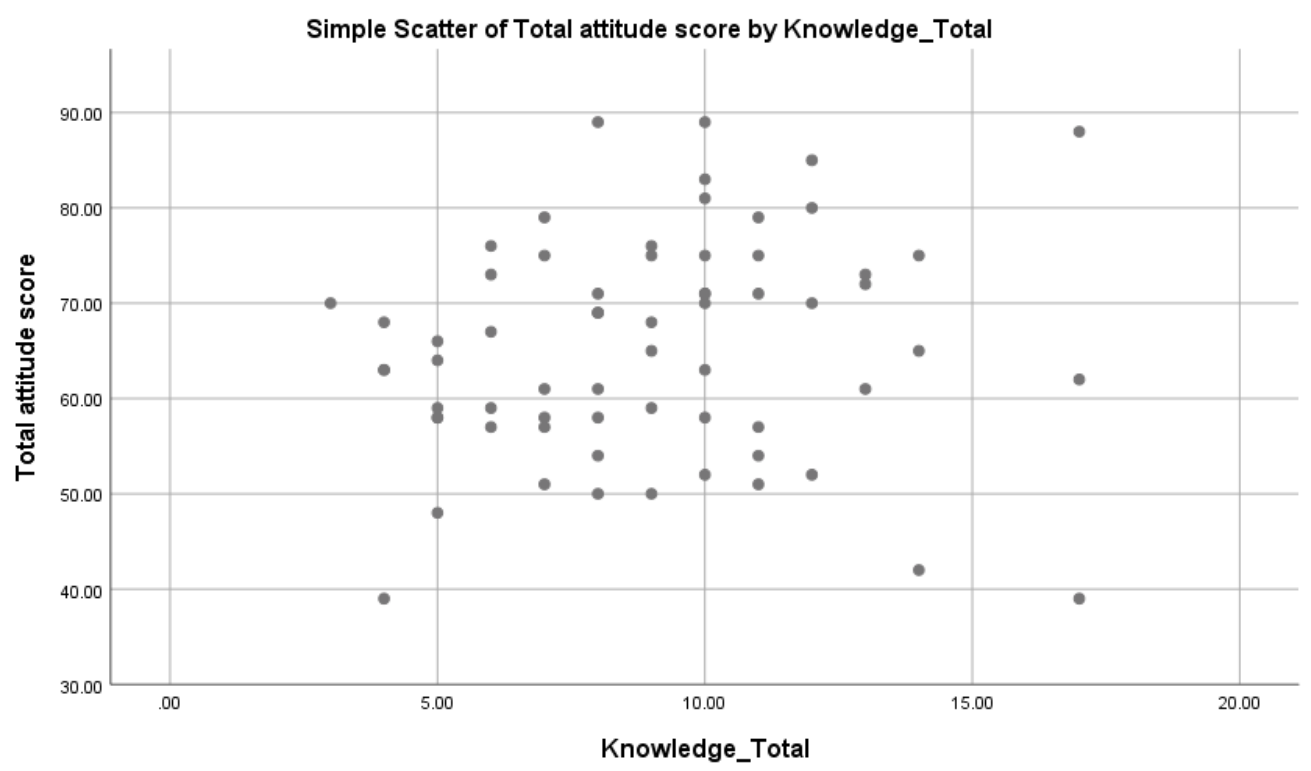


Table 9

Correlation between attitude score and knowledge score

Correlations

\begin{tabular}{llll}
\hline & & $\begin{array}{c}\text { Total attitude } \\
\text { score }\end{array}$ & Knowledge total \\
\hline Total attitude score & Pearson Correlation & 1 & .130 \\
\cline { 2 - 4 } & Sig. (2-tailed) & & .303 \\
\cline { 2 - 4 } & $\mathrm{N}$ & 66 & 65 \\
\hline Knowledge total & Pearson Correlation & .130 & 1 \\
\cline { 2 - 4 } & Sig. (2-tailed) & .303 & 65 \\
\cline { 2 - 4 } & $\mathrm{N}$ & 65 & \\
\hline
\end{tabular}

As shown in Table 10, when the regular-student group data were tested using the Pearson correlation coefficient, the results showed a stronger correlation between the two variable, $\mathrm{r}=.551, \mathrm{n}=29, \mathrm{p}=.002$. According to recommendations, an $\mathrm{r}$ value of greater than 0.5 should be interpreted as large (Pallant, 2005, p. 126; Field, p. 82). The scatter graph in Figure 5 visually represents these data. As shown in Table 11, when the Pearson correlation coefficient was computed for the student-teacher group, a small though not statistically significant negative correlation was found, $\mathrm{r}=-.162, \mathrm{n}=36, \mathrm{p}=.347$. This is visually represented in the scatter graph in Figure 7. There was found to be statistically significant correlation for the regular student group, no such correlation was present for the students on the teacher education programme. No statistically significant correlation was found for the complete sample.

Table 10

Correlations between attitude and knowledge for just the regular student group

\begin{tabular}{llll} 
& & \multicolumn{1}{c}{ Total attitude } & \\
& & score & Knowledge total \\
\hline Total attitude score & Pearson Correlation & 1 & $.551^{* *}$ \\
\cline { 2 - 4 } & Sig. (2-tailed) & .002 \\
\cline { 2 - 4 } & $\mathrm{N}$ & 29 & 29 \\
\hline Knowledge total & Pearson Correlation & $.551^{* *}$ & 1 \\
\cline { 2 - 4 } & Sig. (2-tailed) & .002 & 29
\end{tabular}

**. Correlation is significant at the 0.01 level (2-tailed). 
Figure 6

Simple scatter graph of attitude score by knowledge score for just regular student group

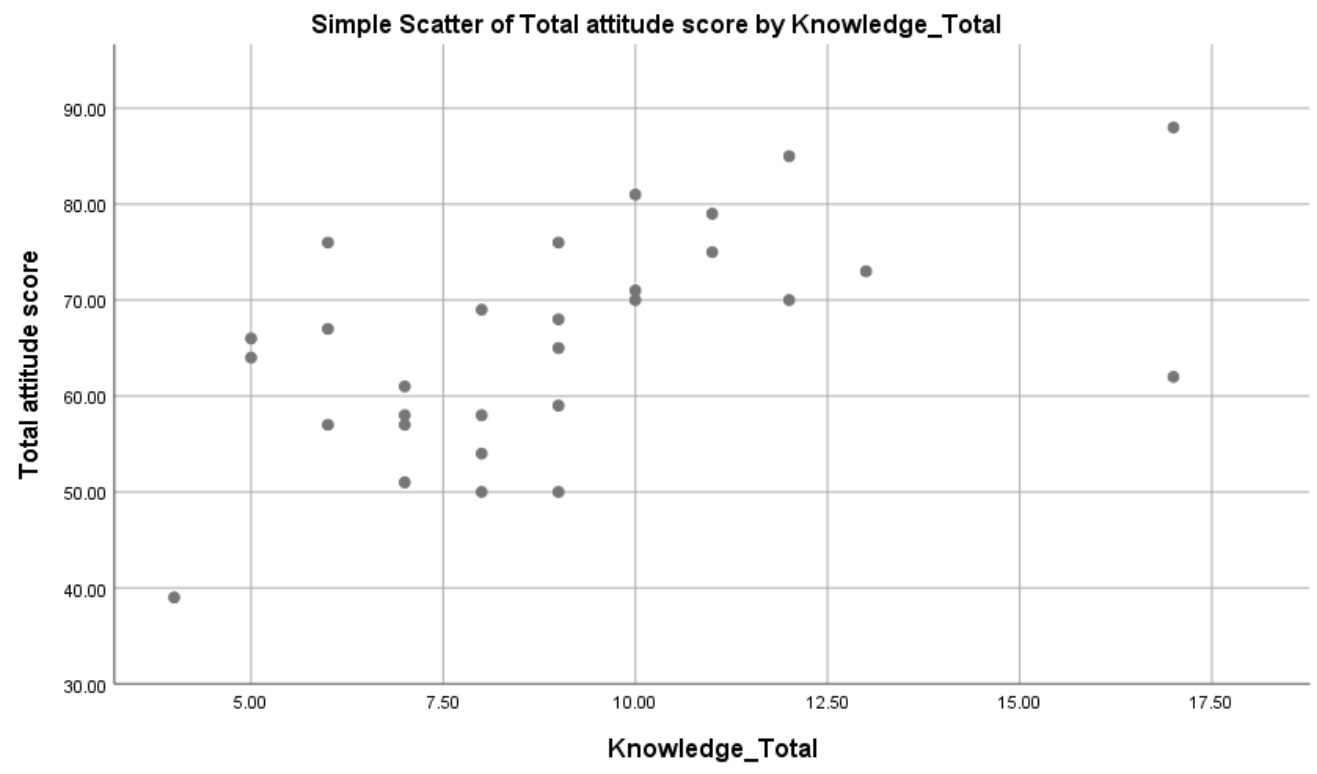

Table 11

Correlation between attitude and knowledge for just the student-teacher group

Total attitude

score Knowledge total

\begin{tabular}{|c|c|c|c|}
\hline \multirow[t]{3}{*}{ Total attitude score } & Pearson Correlation & 1 & -.162 \\
\hline & \multicolumn{2}{|l|}{ Sig. (2-tailed) } & .347 \\
\hline & $\mathrm{N}$ & 37 & 36 \\
\hline \multirow[t]{3}{*}{ Knowledge total } & Pearson Correlation & -.162 & 1 \\
\hline & Sig. (2-tailed) & .347 & \\
\hline & $\mathrm{N}$ & 36 & 36 \\
\hline
\end{tabular}


Figure 7

Simple scatter graph of attitude score by knowledge score for just student-teacher group

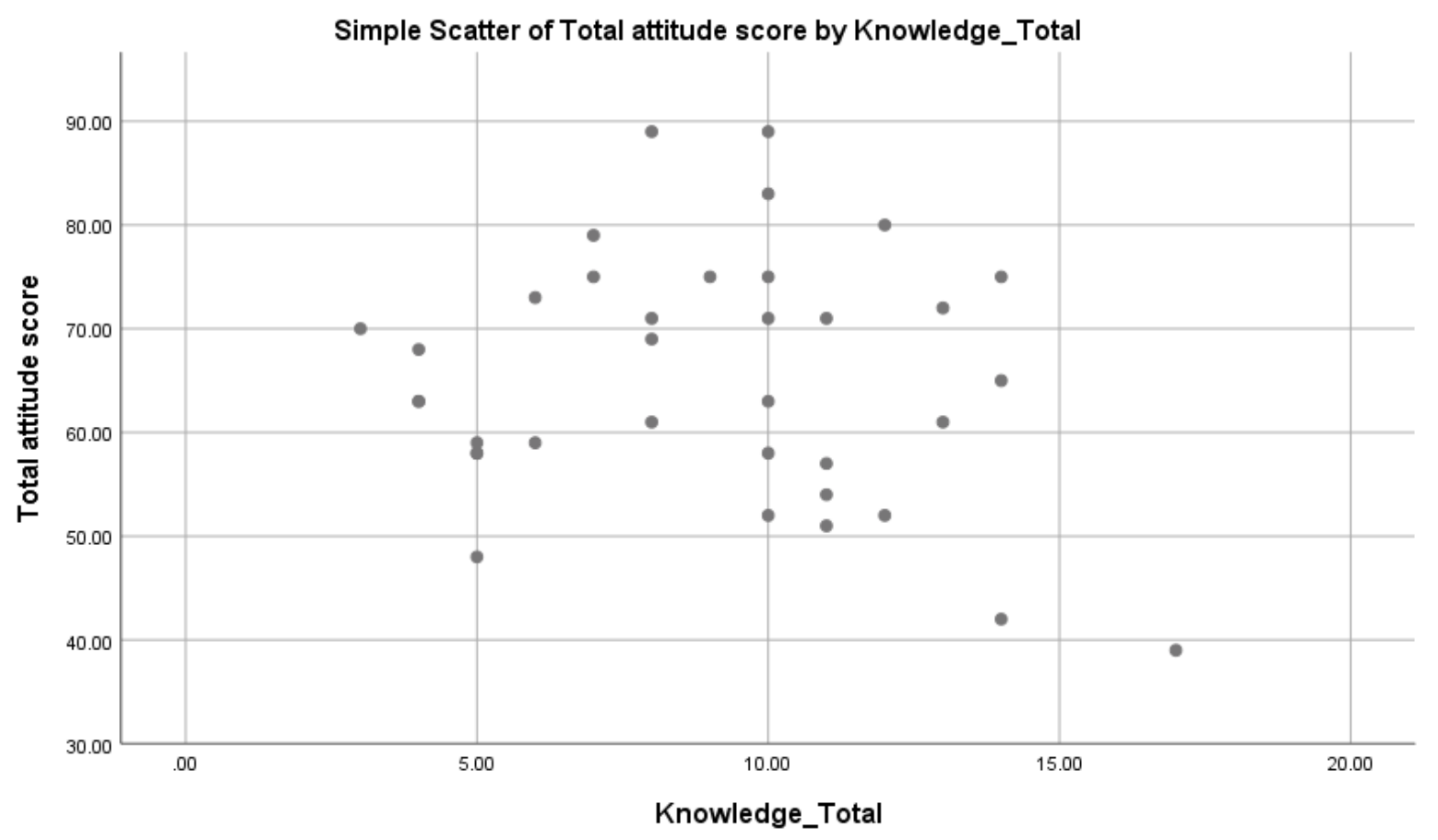

H3 Students' attitudes towards the value of the study of poetry will correlate significantly with their knowledge of poetry analysis. Rejected.

H03 There will be no statistically significant correlation between students' attitudes towards the value of the study of poetry and their knowledge of poetry analysis. Accepted.

\subsubsection{Hypothesis 4}

A multiple regression analysis was performed in order to determine whether attitude towards poetry is predictable based on knowledge score, course type, age and number of university credits. As shown in Table 12 and Table 13, the results of the regression show that the predictive model explained only $5.6 \%$ of the variance, but was not a significant predictor of attitude, $\mathrm{F}(4,57)=.85, \mathrm{p}=.499$. Table 14 shows that, taken independently, no variable is a significant predictor of attitude as all $\mathrm{p}$ values are greater than 0.05 . 
Table 12

Model summary

Std. Error of the

\begin{tabular}{lllll} 
Model & $\mathrm{R}$ & $\mathrm{R}$ Square & Adjusted R Square & Estimate \\
\hline 1 & $.237^{\mathrm{a}}$ & .056 & -.010 & 11.83272
\end{tabular}

a. Predictors: (Constant), Knowledge total, Teacher or regular student, Age,

Credit group

Table 13

ANOVA

\begin{tabular}{lllllll} 
Model & \multicolumn{1}{l}{ Sum of Squares } & df & Mean Square & F & Sig. \\
\hline 1 & Regression & 476.225 & 4 & 119.056 & .850 & $.499^{\mathrm{b}}$ \\
\cline { 2 - 6 } & Residual & 7980.759 & 57 & 140.013 & \\
\cline { 2 - 6 } & Total & 8456.984 & 61 & & \\
\hline
\end{tabular}

Table 14

\section{Coefficients}

Coefficients $^{\mathrm{a}}$

\begin{tabular}{|c|c|c|c|c|c|c|}
\hline \multirow[b]{3}{*}{ Model } & & \multirow{2}{*}{\multicolumn{2}{|c|}{ Unstandardized Coefficients }} & \multirow{3}{*}{$\begin{array}{l}\text { Standardized } \\
\text { Coefficients }\end{array}$} & \multirow[b]{3}{*}{$\mathrm{t}$} & \multirow[b]{3}{*}{ Sig. } \\
\hline & & & & & & \\
\hline & & B & Std. Error & & & \\
\hline \multirow[t]{5}{*}{1} & (Constant) & 49.127 & 10.292 & & 4.773 & .000 \\
\hline & Age & .481 & .375 & .173 & 1.284 & .204 \\
\hline & Credit group & .130 & .902 & .020 & .144 & .886 \\
\hline & Teacher or regular student & -.432 & 3.130 & -.018 & -.138 & .891 \\
\hline & Knowledge total & .597 & .474 & .166 & 1.260 & .213 \\
\hline
\end{tabular}

a. Dependent Variable: Total attitude score

H4 Students' attitudes towards the value of the study of poetry will be predictable based attitude will be predictable based on knowledge, type of English course, age and level of education. Rejected.

H04 Students' attitudes towards the value of the study of poetry will not be statistically predictable based on knowledge, type of English course, age and level of education. Accepted. 


\section{Discussion}

Despite the overall lack of statistically significant results, this study has revealed several interesting outcomes. The results revealed no statistically significant difference between the pre-service teacher group, and the regular-student group in terms of knowledge and attitude towards poetry. The corresponding hypotheses were based on the limited and contradictory existing research (Benton, 1999; Fleming, 1992; Weaven \& Clark, 2014), and thus confidence levels about finding a difference were low. While it is possible that these findings could have been influenced by the problems with reliability outlined above, the fact that the null hypotheses for 1 and 2 were rejected is not entirely contrary to expectations. There may also have been a problem with the grouping of students into regular students and pre-service teachers, because it is likely that some participants in the regular student group may have been following an alternative route into gaining a teaching qualification.

Results of tests run for hypothesis 3 exploring the correlation between attitude and knowledge were of especial interest. Considering previous research into correlations between these constructs in a STEM-education context, a positive correlation might have justifiably been predicted (Alves-Martins, 2002; Kpolovie et al., 2014). However, research into similar correlations in humanities and language-learning education are less decisive (Chihara \& Oiler, 1978; Pierson et al., 1980; Spolsky, 1969), and the present results need to be considered in this context. In the current sample, there could have been a variety of complex internal and external factors at play in determining the results of both constructs, and as previous research suggests, while higher levels of knowledge sometimes mean a more favourable attitude, attitude can be negatively affected by the demands of advanced level study of poetry (Snapper, 2013). Nevertheless, that errors in measurements could have played a role in reducing the likelihood of finding existing correlations should be considered.

It was particularly noteworthy that when the correlations between knowledge and attitude were explored in relation to subgroups, there was found to be a statistically significant correlation between the constructs with the regular-student group. The slight, but nonstatistically negative correlation that was found with the pre-service teacher group would have had the effect of negating any significant positive correlation across the entire sample. The reasons for the notable differences between the two groups are unclear but could suggest that the pre-service teachers had internalised notions of the importance of poetry in the Swedish 
school system (Sigvardsson, 2017). Since there was no statistically significant correlation between knowledge and attitude across the sample, it was not surprising that attitude was not predictable on the basis set out in H4. It would have been illuminating to run the multiple regression analysis for just the regular group in light of the aforementioned finding.

The present study was conducted on a small-scale, and the fact that it utilised convenience sampling greatly affects the generalisability of finding (as discussed in the methods section). Potential errors in measurements could also have impacted on the reliability and validity of results. The knowledge test was particularly problematic, and this could in part be connected to the problems of testing knowledge in an area that is inherently subjective (in interpretation it is difficult to speak of right and wrong answers).

\section{Conclusion}

Future studies which use a larger randomised and stratified sample, and in which reliability and validity of instruments are revisited would be necessary in order to make generalisations about the population. Despite its limitations, this preliminary small-scale study functions as a window on students' knowledge of, and attitude towards poetry from an under researched Swedish context. The findings on the conflicting correlations between knowledge and attitude between regular and pre-service students were particularly interesting and warrant further enquiry. Following up this study with a more qualitatively oriented investigation would potentially shed light on this discrepancy. 


\section{References}

Alfredsson, J. (2018). The "effanineffable" weakness of poetry: The duality of bringing poetry into the teacher training classroom. In S. Kleppe \& A. Sorby (Eds.), Poetry and pedagogy across the Llifespan (pp. 237-253). Cham: Palgrave Macmillan.

Alves-Martins, M., Peixoto, F., Gouveia-Pereira, M., Amaral, V., \& Pedro, I. (2002). Selfesteem and academic achievement among adolescents. Educational Psychology, 22(1), 51-62. https://doi.org/10.1080/01443410120101242

Bennett, A., \& Royle, N. (2004). An introduction to literature, criticism and theory. London: Routledge.

Benton, P. (1999). Unweaving the rainbow: Poetry teaching in the secondary school I. Oxford Review of Education, 25(4), 521-531. https://doi.org/10.1080/030549899103964

Bryman, A., \& Cramer, D. (1997). Quantitative data analysis with SPSS for Windows. London: Routledge.

Certo, J., Apol, L., Wibbens, E., \& Hawkins, L. (2012). Living the poet's life: Using an aesthetic approach to poetry to enhance preservice teachers' poetry experiences and dispositions. English Education, 44(2), 102-146. http://www.jstor.org/stable/23238751

Cheung, K. (1988). Outcomes of schooling: Mathematics achievement and attitudes towards mathematics learning in Hong Kong. Educational Studies in Mathematics, 19(2), 209219. https://doi.org/10.1007/BF00751233

Chihara, T., \& Oiler Jr, J. W. (1978). Attitudes and attained proficiency in EFL: A sociolinguistic study of adult Japanese speakers. Language Learning, 28(1), 55-68. https://doi.org/10.1111/j.1467-1770.1978.tb00304.x

Cohen, L., \& Holliday, M. (1982). Statistics for social scientists. London: Harper \& Row. 
Dörnyei, Z., \& Taguchi, T. (2010). Questionnaires in second language research: Construction, administration, and processing. New York: Routledge.

Dymoke, L., Lambirth A. \& Wilson, A. (2013). Introduction. In S. Dymoke, A. Lambirth \& A. Wilson, Anthony (Eds.), Making poetry matter: International research on poetry pedagogy (pp.1-8). London: Bloomsbury.

Eagleton, T. (2007). How to read a poem. Maldon, MA: Blackwell Publishing.

Farrokhi, F., \& Mahmoudi-Hamidabad, A. (2012). Rethinking convenience sampling: Defining quality criteria. Theory \& Practice in Language Studies, 2(4), 784-792. https://doi:10.4304/tpls.2.4.784-792

Field, A. (2014). Discovering statistics using IBM SPSS statistics (4 ${ }^{\text {th }}$ ed.). London: Sage Publications.

Fleming, M. (1992). Pupils' perceptions of the nature of poetry. Cambridge Journal of Education, 22(1), 31-41. https://doi.org/10.1080/0305764920220104

George, D., \& Mallery, P. (2016). IBM SPSS statistics 23 step by step: A simple guide and reference. New York: Routledge.

Ghazali, S. N. (2016). Learner background and their attitudes towards studying literature. Malaysian Journal of ELT Research, 4(1), 1-17. http://www.melta.org.my/journals/index.php/majer/article/view/198/108

Henry, G. T. (1990). Applied social research methods: Practical sampling. Thousand Oaks, CA: SAGE Publications. http://dx.doi.org/10.4135/9781412985451

Hirvela, A., \& Boyle, J. (1988). Literature courses and student attitudes. ELT Journal, 42(3), 179-184. https://doi.org/10.1093/elt/42.3.179

Isaacs, W. (1999). Dialogue: The Art of Thinking Together. New York: Random House. 
Jonker, J., \& Pennink, B. (2010). The essence of research methodology: A concise guide for master and PhD students in management science. New York: Springer.

Kumar, R. (2008). Research methodology. New Delhi: APH.

Liao, F., \& Roy, S. (2017). EFL students' perceptions of writing poetry in English: The effect of educational backgrounds and belief towards poetry. The Journal of Literature in Language Teaching, 6(1), 55-72. http://liltsig.org/wp-content/uploads/2014/12/lilt6_1-Liao-Roy.pdf

Ma, X., \& Kishor, N. (1997). Assessing the relationship between attitude toward mathematics and achievement in mathematics: A meta-analysis. Journal for Research in Mathematics Education, 21(1), 26-47. https://jstor.org/stable/749662

McMillan, J. H. (1996). Educational research: Fundamentals for the consumer. New York: HarperCollins.

Merriam-Webster. (n.d.). Retrieved from https://www.merriam-webster.com/

Neale, D. C. (1969). The role of attitudes in learning mathematics. The Arithmetic Teacher, 16(8), 631-640.

Nieswandt, M. (2007). Student affect and conceptual understanding in learning chemistry. Journal of Research in Science Teaching: The Official Journal of the National Association for Research in Science Teaching, 44(7), 908-937. https://doi.org/10.1002/tea.20169

Nilsson, S. K. (2016). Young Adults in Sweden on Reading Literary Fiction in Print and Electronic Media. CLCWeb: Comparative Literature and Culture, 18(2), https://doi.org/10.7771/1481-4374.3140> 
Oliver, J. S., \& Simpson, R. D. (1988). Influences of attitude toward science, achievement motivation, and science self concept on achievement in science: A longitudinal study. Science Education, 72(2), 143-155. https://doi.org/10.1002/sce.3730720204

Oppenheim, A.N. (1992). Questionnaire Design, Interviewing and Attitude Measurement. London: Continuum.

Osborne, J. W., \& Overbay, A. (2004). The power of outliers (and why researchers should always check for them). Practical assessment, research \& evaluation, 9(6), 1-12. http://pareonline.net/getvn.asp?v=9\&n=6

Pallant, J. (2005). SPSS survival manual: A step guide to data analysis using SPSS for Windows version 12. Maidenhead: Open University Press

Pell, A. W. (1985). Enjoyment and attainment in secondary school physics. British Educational Research Journal, 11(2), 123-132. https://doi.org/10.1080/0141192850110205

Pierson, H. D., Fu, G. S., \& Lee, S. Y. (1980). An analysis of the relationship between language attitudes and English attainment of secondary students in Hong Kong. Language Learning, 30(2), 289-305. https://doi.org/10.1111/j.1467-1770.1980.tb00320.x

Poetry Foundation. (n.d.). Retrieved from https://www.poetryfoundation.org/

Ray, R. (1999). The diversity of poetry: How trainee teachers' perceptions affect their attitudes to poetry teaching. Curriculum journal, 10(3), 403-418. https://doi.org/10.1080/0958517990100306

Reynolds, A., \& Walberg, H. (1992). A process model of mathematics achievement and attitude. Journal for Research in Mathematics Education, 23(4), 306-328. https://doi:10.2307/749308

Sigvardsson, A. (2017). Teaching poetry reading in secondary education: Findings from a systematic literature review. Scandinavian Journal of Educational Research, 61(5), 584-599. https://doi.org/10.1080/00313831.2016.1172503 
Snapper, G. (2013). Exploring resistance to poetry in advanced English studies. In S. Dymoke, A. Lambirth \& A. Wilson, Anthony (Eds.), Making poetry matter: International research on poetry pedagogy (pp.31-41). London: Bloomsbury.

Spolsky, B. (1969). Attitudinal aspects of second language learning. Language Learning, 19(34), 271-275.

Wade, B., \& Sidaway, S. (1990). Poetry in the curriculum: A crisis of confidence. Educational Studies, 16(1), 75-83. https://doi.org/10.1080/0305569900160106

Warner, R. M. (2008). Applied statistics: From bivariate through multivariate techniques. New York: Sage.

Weaven, M., \& Clark, T. (2013). 'I guess it scares us': Teachers discuss the teaching of poetry in senior secondary English. English in Education, 47 (3), 197-212. https://doi.org/10.1111/eie.12016

Weaven, M., \& Clark, T. (2014). An undeclared schism: Higher and secondary learning about poetry. Journal of language, literature and culture, 61(2), 142-149. https://doi.org/10.1179/2051285614Z.00000000036

Xerri, D. (2014). 'Poetry is a tremendous ally': Children's poet Michael Rosen on teachers' attitudes toward poetry. New Review of Children's Literature and Librarianship, 20(2), 112-122. https://doi.org/10.1080/13614541.2014.929439 


\section{Appendix 1}

\section{Background information and attitude scale}

\section{Poetry Questionnaire}

Before you begin the survey, please complete the below background information:

Course code:

Year of birth:

How many university credits do you already hold?:

Have you studied literature at university level prior to this course: yes/no

Please read the following statements and place a cross $\mathbf{X}$ in the box which best describes your attitude $(5=$ strongly agree; 1 = strongly disagree).

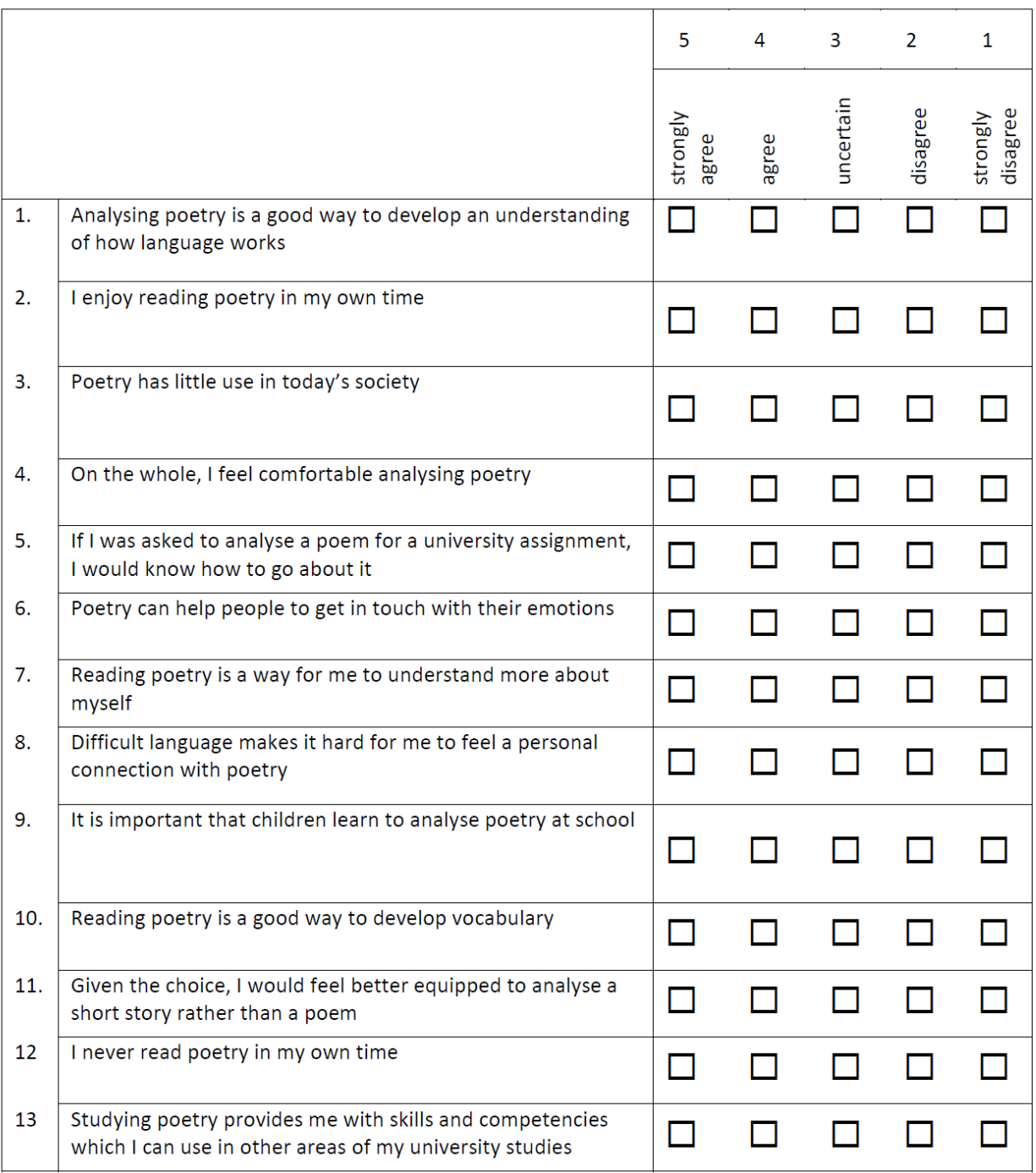




\begin{tabular}{|c|c|c|c|c|c|c|}
\hline & & 5 & 4 & 3 & 2 & 1 \\
\hline 14 & I would rather read a novel than a collection of poetry & $\square$ & $\square$ & $\square$ & $\square$ & $\square$ \\
\hline 15 & $\begin{array}{l}\text { Poetry enables me to understand more about the world I live } \\
\text { in }\end{array}$ & $\square$ & $\square$ & $\square$ & $\square$ & $\square$ \\
\hline 16 & Reading poetry is boring and I only do it if I have to & $\square$ & $\square$ & $\square$ & $\square$ & $\square$ \\
\hline 17 & Poetry analysis is a valuable exercise in critical thinking & $\square$ & $\square$ & $\square$ & $\square$ & $\square$ \\
\hline 18 & I find poetry difficult to understand & $\square$ & $\square$ & $\square$ & $\square$ & $\square$ \\
\hline 19 & $\begin{array}{l}\text { Poetry has the capacity to open one's perspective to a } \\
\text { greater range of possibilities }\end{array}$ & $\square$ & $\square$ & $\square$ & $\square$ & $\square$ \\
\hline 20 & Poetry is relevant to my own life & $\square$ & $\square$ & $\square$ & $\square$ & $\square$ \\
\hline
\end{tabular}




\section{Appendix 2}

\section{Knowledge test}

Read each question and then circle the letter of the correct answer.

1. Which of the following lines contains the strongest example of alliteration?
a. of something missed, flash-pop or empty frame.
b. I love whatever doesn't get too close
c. my senses swoon. A synonym for stay,
d. bleached street-lit things, I'm best at moving on.

2. What term is the following a definition of: "the running over of a sentence from one verse or couplet into another so that closely related words fall in different lines"
a. ellipsis
b. enjambment
c. epigraph
d. end rhyme

3. Which of the following is a metaphor?
a. A thing of beauty is a joy for ever
b. Beauty is truth, truth beauty
c. being beautiful is a kind of a duty
d. beauty is like a rotten tooth

4. Which of the following lines is in iambic pentameter?
a. She walks in beauty, like the night
b. If music be the food of love, play on;
c. The guests are met, the feast is set:
d. I wandered, lonely as a cloud

5. Which of the following lines does not contain an example of onomatopoeia?
a. Of lamentation, like a wind, that shrills
b. How they clang, and clash, and roar!
c. Pop, plop, plunk, pow
d. the window you've picked is a black

6. An oxymoron is:
a. a combination of contradictory or incongruous words
b. a combination of words with analogous meanings
c. a combination of metaphors and similes
d. a combination of words used to create irony 


\section{Ellen Turner}

7. What figure of speech is present in the following line: “I'm a black ocean, leaping and wide,"
a. Personification
b. Simile
c. Metaphor
d. Synecdoche

8. Which of the following lines is end stopped?
a. I am forced to sleepwalk much of the time.
b. We hold on to these old ways, are troubled
c. who eluded me even in my sleep? That was a particularly
d. shook his head, the evangelist balanced two spools

9. A dactyl is:
a. a metrical foot in which a long syllable is followed by two short syllables
b. a metrical foot in which a short syllable is followed by two long syllables
c. a metrical foot in which a long syllable is followed by three short syllables
d. a metrical foot in which three short syllables are followed by a long syllable

10. Which of the following lines contains an example of personification?
a. Shall I part my hair behind? Do I dare to eat a peach?
b. Combing the white hair of the waves blown back
c. We have lingered in the chambers of the sea
d. Till human voices wake us, and we drown.

11. A stanza is:
a. a 14-line poem
b. a grouping of lines which form a unit in a poem
c. a metrical foot in which a long syllable is followed by two short syllables
d. a rhyming couplet

12. Which of the following lines does not contain a simile?
a. her fingers as long and thin as straws
b. circling the abyss like a shark
c. her uterus an empty teacup
d. I wear tubes like earrings 
13. Which of the following is tautological?

a. She married: - O, most wicked speed, to post/ With such dexterity to incestuous sheets!

b. O that this too solid flesh would melt,/ Thaw, and resolve itself into a dew!

c. A little month; or ere those shoes were old/ With which she followed my poor father's body

d. Ere yet the salt of most unrighteous tears/ Had left the flushing in her galled eyes,

14. How many lines does a sonnet have?
a. 11
b. 12
c. 13
d. 14

15. What feature is present in the following lines?: "I should have been a pair of ragged claws/ Scuttling across the floors of silent seas."
a. synecdoche
b. simile
c. personification
d. irony

16. Which of the following is correctly describes anapest?

a. a metrical foot consisting of two short syllables followed by one long syllable or of two unstressed syllables followed by one stressed syllable

b. a metrical foot consisting of one short syllable followed by one long syllable or one unstressed syllable followed by one stressed syllable

c. a metrical foot consisting of three short syllables followed by one long syllable or of three unstressed syllables followed by one stressed syllable

d. a metrical foot consisting of two short syllables followed by two long syllables or of two unstressed syllables followed by two stressed syllable

17. What feature is present in the following lines?: "The sense of gravity sitting in tissue is like the space between/carcass and curb, before the reek worms into rock pores:"
a. simile
b. hyperbole
c. irony
d. oxymoron 
18. What is hyperbole?
a. exemplification
b. experimentation
c. exaggeration
d. exceptionalism

19. What technique is present in the following lines?: "April is the cruellest month, breeding / Lilacs out of the dead land"
a. pastiche
b. palindrome
c. personification
d. pun

20. Which of the below lines contains the least alliteration?
a. Mother rain, manifold, measureless
b. The dogwood cowered under the thunder
c. making every moment movement.
d. souls in your ceaseless descent 